\title{
The examination of teacher student communication process in the classroom: mathematical communication process model
}

\author{
Büşra Sür ${ }^{1 a}$, Ali Delice ${ }^{2}$ \\ ${ }^{1}$ Ministry of National Education, Prof. Dr. Mustafa Zengin Secondary School, İstanbul, 3400, Turkey \\ ${ }^{2}$ Marmara University, Ataturk Faculty of Education, Istanbul, 3474, Turkey
}

\begin{abstract}
When it is taken into account that educational environments include communication processes between teachers and students, the existence of mathematical communication processes in math classes can also be mentioned. In this communication process, mathematic is considered as a lingua franca which ensure mutual understanding and using mathematical sentences - setting up a model, making a logical inferences, using mathematical symbols and abstraction are behaviors being expected from communicators. In this study, which is a part of a larger-scale study, it is discussed whether functional communication model can be obtained by deeply analyzing the communication between teacher and student in mathematics education process. This study is conducted by 9 th grade students from two branches and two mathematics teachers, teachers' ways of using the language of mathematics have been compared by observing the mathematical communication processes during teaching the triangles. Content analysis has been made to observation data. It has been seen that mathematical communication process has a dynamic pattern. More than one factor affecting the process emerged. Therefore, it is concluded that mathematical communication is a process which must be handled multidimensional and functional model emerged.
\end{abstract}

\section{Introduction}

Communication, which communicators are expected to act depending on information they interchange [13], is a cyclic process which includes sequential behaviours depending on an action and a reaction between the source and receiver [14]. Educational environments include communication processes between teachers and students. When every class is regarded as a communication environment which can be handled within itself, math classes can be considered as a process practiced by using objects belong to mathematics. Mathematics, which forms this process, must be handled as a lingua franca which ensures

\footnotetext{
${ }^{a}$ Corresponding author: busrasur16@gmail.com
} 
people to make sense of universe [7] beyond being an object in which basic calculations are made. The ability to use this language effectively is equal to understand, interpret and produce what is said [3]. In mathematical communication processes, using mathematical sentences - setting up a model, making a logical inferences, using mathematical symbols and abstraction are behaviours expected from communicators [1]. Cognitive levels defined in Bloom's Taxonomy [2] can be shown as reasons to these behaviours. Original information is possible when learning of individuals progresses from comprehension level to synthesis level. Hence, in mathematical communication processes, information which transferred as a message must be taught individuals in high level. In this regard, teachers' ways to guide students to synthesis, used language and communication types can be analyzed. In learning mathematics, language is crucial and is handled by different theoretical perspectives [8]. In the study, mathematics teachers' ways of using mathematics as a language have been analyzed and whether a functional model can be obtained has been discussed by analyzing communication between teacher and student deeply in mathematics education process.

\section{Method}

Method is required to clarify theoretical framework of the study, with whom to collaborate, the way of obtaining data [9]. Therefore, in this chapter the paradigm of the study, pattern, participants, and methods and techniques to collect data will be explained one by one.

\subsection{Paradigm and Design}

Scientific methods, which are used in studies, change according to the researchers' points of view about scientific knowledge [6]. Paradigms, which are common idea accepted in a study field in a specific time [10], are the most general framework stating the researchers' view about knowledge [14]. In the study, to put forward mathematical communication process holistically has been aimed. This aim has been formed in the light of the qualitative paradigm which enables to descript deeply and give an opportunity to interpret [15]. It is a qualitatively-oriented study and puts forward a case. It is a case study because mathematical communication processes between students and teachers during the subject triangles have been analyzed and interpreted deeply [5].

\subsection{Study Group}

The sample was selected as small groups which revealed the situation. Hereby, to obtain in-depth information was aimed. With this aspect, sample selection is a purposive sampling [11]. In a study handled with 9th grades in an Anatolian high school, there were 68 students from 2 different classes and mathematics teachers. In each class which contained 34 students, 2 different teachers gave the lecture. Classes were used as $\mathrm{C} 1$ and $\mathrm{C} 2$ codes.

\subsection{Data Collection Tool}

Data are obtained by observing participants in the studies which researchers analyze social conditions deeply in their habitat and obtain the data of 'active' and 'natural' [4]. In a technique of observation, which is variant depending on the role of the researcher in a process, collecting information by interacting with the participant during the case is participant observation [12]. In this way, to learn the reasons of participants' behaviours is 
aimed. In this context, teachers and students' mathematical communication processes were observed in the math classes which are social learning environments. Researcher involved in the process and analyzed the reasons for the behaviours. Observations which were made 7 weeks long, took place as an intermittent observation [4]. Non-successive classes were examined and observations were made as an unfigured with the purpose of handling holistically. Data were obtained by following the process with sound recording and field notes. In the study which is a part of a comprehensive study, teachers' written and verbal types of using mathematical language and its effects were analyzed. 8 hours of classes contains gains on common depending on teachers' speed of using time. The rest of the observations consist of different gains.

\subsection{Analysis of Data}

In the study in which the effects of mathematical language on students were examined, teachers' types of using mathematical language were evaluated. Observation data were examined through making content analysis. Two different classes and teachers were observed in the study and instead of comparative analysis, complementarity analysis was used with the aim of putting forward the all variables of the process. In other word, findings were not evaluated according to the existence in $\mathrm{C} 1$ and $\mathrm{C} 2$, but evaluated according to accurement in mathematical communication process. While common behaviours of teachers and students were analyzed firstly in common gains, the behaviours which differentiate the process were prioritized in uncommon gains.

\section{Findings}

It was seen that mathematical process was a process between one or more than one individual. With the content analysis of mathematical communication process, which was evaluated according to the individuals' relationships with each other in classroom environment, observation data were handled and consequently three different types emerged;

- The communication process performed by students and teachers (Teacher Student Communication)

- The communication process students perform with each other (Student-Student Communication)

- The communication process students perform with themselves (Internal Communication of the Students)

Teachers' and students' density of status in the mathematical communication process changed. This density varied depending on the content and duration of teaching. At either case, activity of teachers or students in a process changed. It was seen that continuity of mathematical communication between teachers and students in and out of class had changed based on activity. During the observations in class $\mathrm{C} 1$, it was observed that teacher was mainly active. And in the class $\mathrm{C} 2$ students were more active. In mathematical communication processes, which had the same gains, communication period in second class was more than first class. In a similar way, activeness of students also increased mathematical communication period (Figure 1) 


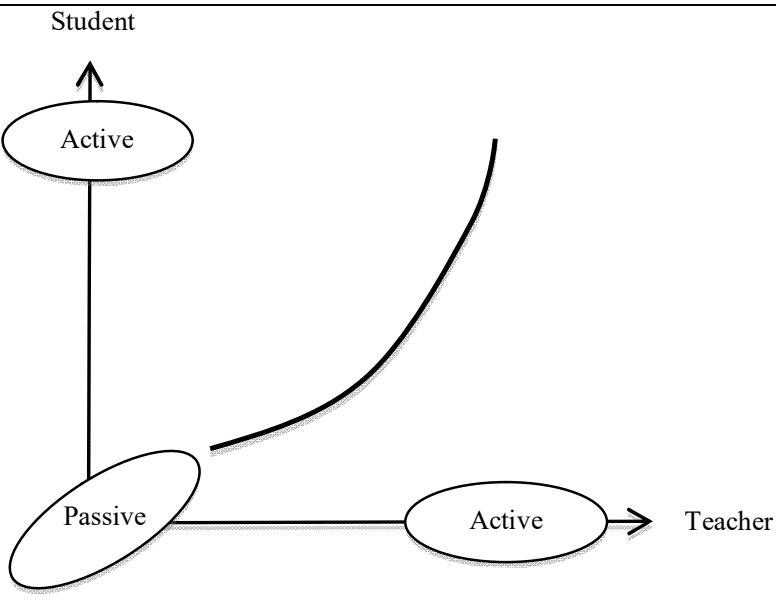

Figure 1: The Exchange Graph of communication time depending activity of teachers and students

From these processes, which happened in two classes, teacher-student communication occurred more frequent in the classroom. On the other hand, student-student communication was encountered more frequently out-of-class (Figure2).
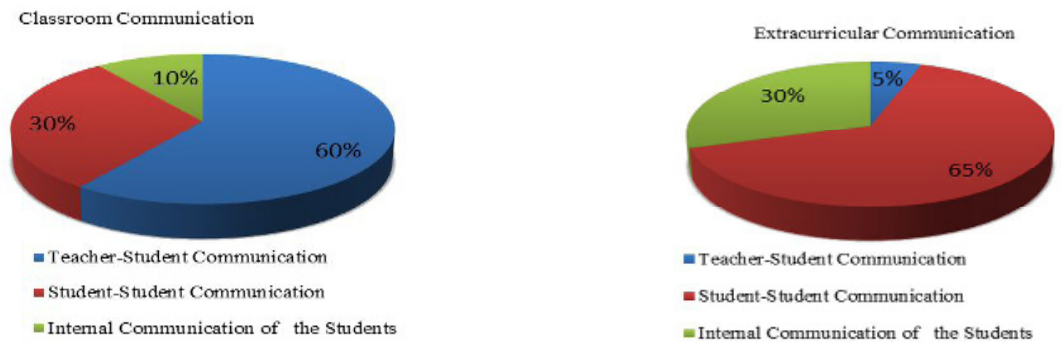

Figure 2: Change of communication processes according to the time

Behaviours were specified, which were shown in mathematical communication processes. It was seen that educational effectiveness in mathematical communication processes in class occurred in the form of conversations. $70 \%$ of this period was far from the symbolic structure of mathematics, and was description-based. Besides, feedback was sent in written in response to dialogue from time to time within the process. In this type of communication, generally symbolic and numerical structure of mathematics was used. On the other hand, in the communication processes in which only writing was used, mainly symbolic and numerical structure of mathematics was used. In this process that generally emerged in problem-solving, shapes, numbers, equations were used based on the subject which was being studied.

In evaluations which depending on the content of teaching, it was seen that in both classes the objects, which form the symbolic structure of mathematics in mathematical communication, were used. Besides, the communication processes occurred, which use only verbal statements. Additionally, there were the situations that verbal statements supported the mathematical objects. While mathematical objects were used in written communication, verbal descriptions were in the form of verbal communication. For instance, in a mathematical communication process which occurs during a problem-solving in a class, a part of a dialogue in the first class is like; 


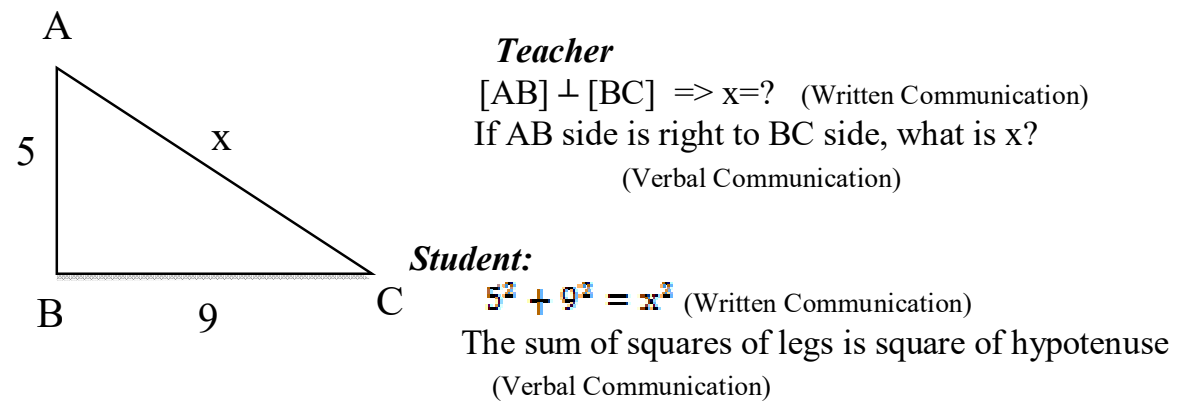

\section{Discussion and Conclusion}

In mathematical communication process, which is considered within the context of the relationships of individuals, more than one type of communication emerged and this showed us that individuals got involved the process periodically in educational environments. Moreover, being different of the communication between teachers and students in and out of class, was interpreted as the process must be evaluated by time.

It was seen that the written communication of teachers maintained the continuity of the mathematical communication process. That the written communication process must be supported by verbal communication process was determined. It was concluded that mathematical communication process must be regarded as written and verbal processes. In this context, a modelling related to language and individual is possible. Names are important for the next phases of the communication, because they are taken as symbols which express objects successfully [13]. Thereby, in communication process, describing the mathematical objects is significant. As in the example, not showing the edge angle on the shape is considered as a positive behaviour in terms of reading the question text. Moreover, it is thought that stating the question text in verbal, has a directive effect. Thus, it was concluded that written and verbal communication processes must be used together in mathematical communication processes.

It was concluded that the mathematical communication process was an interaction, which occurred by using mathematical objects and verbal descriptions with individuals themselves or different individuals. This interactive process must be considered as multidimensional [14]. Observations showed that the mathematical communication process could be handled within the context of "person", "time", "type" and "language units". Thus, it was revealed that mathematical communication was a process which could be studied in four main aspects basically. The aspects can be evaluated as the areas of investigation of the mathematical communication process. It is thought that when handled comparatively with each other, the factors which affect the mathematical communication process contribute to put forward through linguistic content. Therefore, the themes which belong to the analysis process in the studies, where the mathematical communication process was discussed, emerged (Figure 3).

Besides, it was specified that there were two aspects which provided every process to be an area of investigation in itself. Because the intensity of observations was in class, it was seen that the communication process in class also had a written and verbal aspects. It was specified that when these two aspects were matched, there could be three different subareas. Moreover, based on the effect of the activeness of teachers and students on communication periods, it was possible to study as a three different area of investigation (Figure 4). 


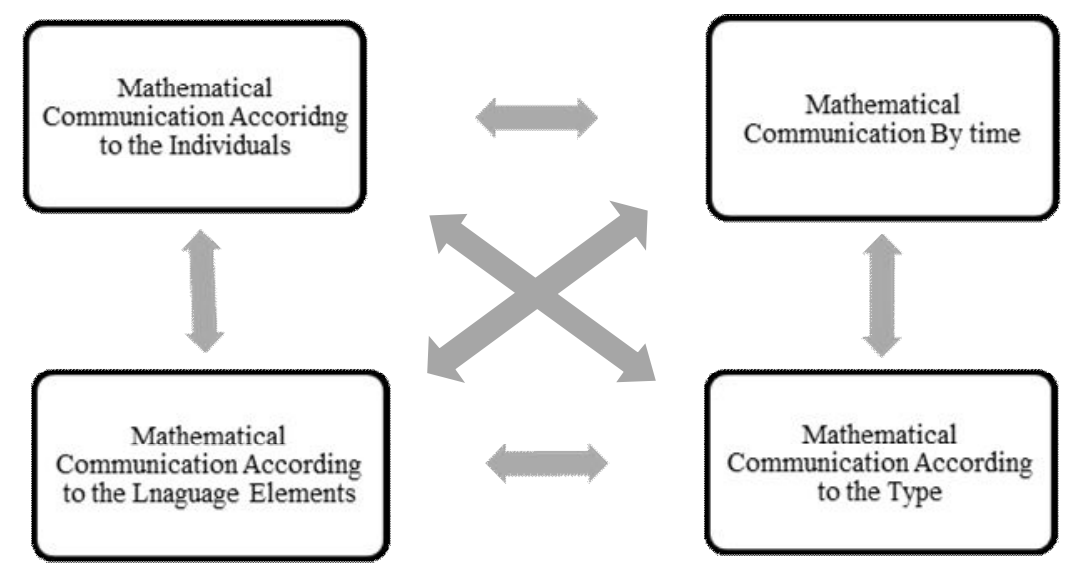

Figure 3: The dimensions of the mathematical communication process

The studies, where the descriptions of the mathematical objects in class were handled in context with the symbols and verbal statements, can be regarded as another research area in modelling of the mathematical communication process. Furthermore, it was revealed that the communication skill, which got involved to mathematics teaching program, must be provided to be functional in practice

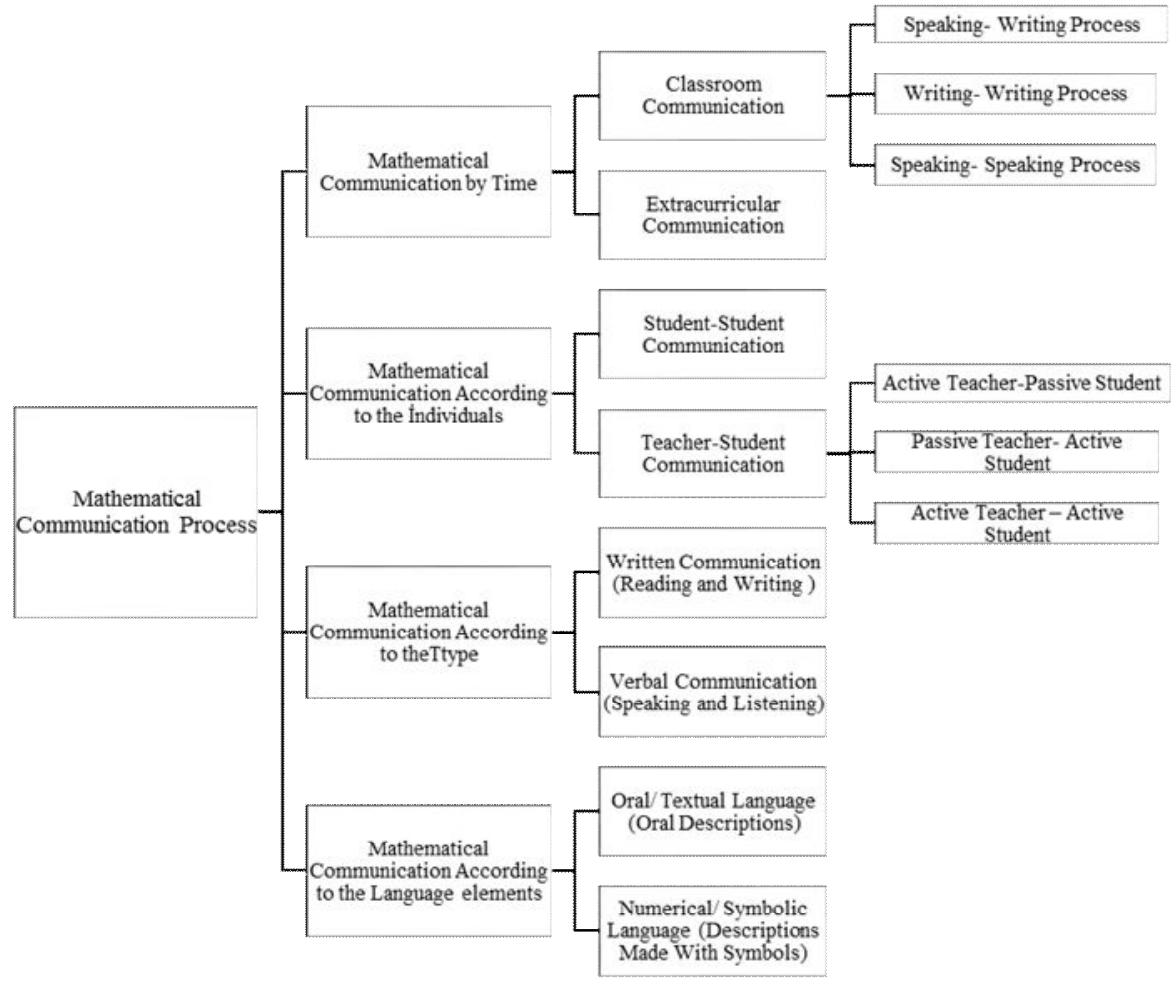

Figure 4: Mathematical Communication Process 


\section{References}

1. Baki, A., Kuramdan Uygulamaya Matematik Eğitimi. Ankara: Harf EğitimYayıncılık (2008)

2. Bloom B S (ed.), Taxonomy of Educational Objectives, the classification of educational goals - Handbook I: Cognitive Domain New York: McKay (1956)

3. Chomsky, N., Dil ve Zihin. (A. Kocaman, Çev.) Ankara: Ayraç Yayıncılık. . (2001)

4. Cohen, L., Manion, L. \& Morrison, K., Research Methods in Education (Sixth Edition).New York: Routledge (2007)

5. Çepni, S., Araştırma ve Proje Çalışmalarına Giriş. Trabzon: Celepler Matbaa (2012)

6. Dobbin, S. A., \& Gatowski, S. I. The judge' deskbook on the basic philosophies and methods of science (1999)

7. Emiroğlu,H. \& Görgülü, N., Hukukun Matematiksel Olarak İfade Edilmesi, Ankara Üniversitesi Hukuk Fakültesi Dergisi, 62, 73-92 (2013)

8. Ferrari, P. L., Matematical Language and Advanced Mathematics Learning. Proceedings of the 28th Conference of the International Group for the Psychology of Mathematics Education, Vol 2 pp 383-390 (2004)

9. Guba, E. G. ve Lincoln, Y. S., Competing paradigms in qualitative research. In N. Denzin ve Y. Lincoln (Eds.), Handbook of qualitative research, Sag Publications (1994)

10. Kuhn, T. S., Bilimsel Devrimlerin Yapısı. (N. Kuyaş, Trans.) İstanbul: Kırmızı yayıncilik (2010)

11. Patton, M. Q. Nitel Araştırma ve Değerlendirme Yöntemleri (3. Baskıdan çeviri).(M. Bütün, \& D. B. Selçuk, Dü) Ankara. Pegem Akademi (2014)

12. Robson, C., Real World Research (Second Edition).UK: Blackwell Publishing (2002)

13. Sierpinska, A., Understanding in Mathematics .Bristol, USA: The Falmer Press (2005)

14. Sür, B., Matematiksel Öğelerin Yazılı ve Sözlü Matematiksel İletişime Yansımalarının 9. Sınıf Üçgenler Konusu Bağlamında İncelenmesi. Basılmamış Yüksek Lisans Tezi. Marmara Üniversitesi (2015)

15. Yıldırım, A., \&Şimşek, H., Sosyal Bilimlerde Nitel Araştırma Yöntemleri. Ankara: Seçkin Yayıncılık (2011) 